\title{
IMPROBIDADE ADMINISTRATIVA COMO FORMA DE CORRUPÇÃO
}

O servidor público submete-se, no exercício do cargo ou função, a obrigações e deveres que são regidos pelo princípio da legalidade, o qual se vincula a outros princípios essenciais, estabelecidos na Constituição e nas leis ou regulamentos, entre eles o da finalidade e o da moralidade administrativa.

Em decorrência desses princípios, o servidor público tem, como forma substancial de sua atividade, o dever de boa administração e a prática da probidade administrativa, derivada do interesse público e o código de ética da relação jurídica entre o servidor público e a Administração, visando à razoabilidade, impessoalidade e eficiência no desempenho dos cargos ou funções públicas.

Nos termos do art. $37, \S 4^{\circ}$ da atual Constituição Federal, a improbidade administrativa tem, como espécies de sanção, "a suspensão dos direitos políticos, a perda da função pública, a indisponibilidade dos bens e o ressarcimento ao erário, na forma e na gradação previstas em lei, sem prejuízo da ação penal cabível". A improbidade, administrativa configura, entre outras modalidades, a hipótese de crime de responsabilidade do Presidente da República" (art. 85, n. V).

A probidade administrativa é, em suma, a norma que rege a conduta do agente público como elemento subjetivo na prática do serviço público, cuja violação caracteriza o instituto da improbidade administrativa, regulada de modo especial na Lei $\mathbf{n}$. $8.429 / 92$.

Como seus antecedentes, do ângulo da condenação do enriquecimento ilícito, cabe indicar a Lei n. 3.164/57 (Lei Pitombo-Godoy Ilha) e a Lei n. 3.502/58 (Lei Bilac Pinto).

A primeira lei submete a seqüestro e perda, em favor da Fazenda Pública, os bens adquiridos pelo servidor público por influência ou abuso do cargo ou função pública ou de emprego em autarquia.

A segunda lei prevê igual sanção ao servidor público ou empregado em autarquia, sociedade de economia mista e fundação pública, beneficiário de enriquecimento ilícito, definindo-se, no art. $2^{\circ}$, seis tipos de infrações dessa natureza.

O princípio da improbidade é uma decorrência do princípio da moralidade que venha a ser violado pela conduta ilícita do servidor público e encontra disciplina nas 
sucessivas Constituições: a do Império (1824) tornava responsáveis os Ministros de Estado por qualquer dissipação de bens públicos, por peita, suborno ou concussão, ainda que agissem por ordem do Imperador (arts. 133, 134 e 135.).

A primeira Constituição republicana, de 1891, define, entre os crimes de responsabilidade do Presidente da República, o atentado contra a "probidade administrativa" (art. 54, n. 6).

A mesma norma se reproduz na Constituição de 1934 (art. 57, alínea f); na Constituição de 1937 (art. 85, alínea d), na de 1946 (art. 89, n. V, com redação alterada pelo Ato Institucional n. 14, de 5.09.69); na de 1967 (art. 84, n. V) e na Emenda Constitucional n. 1, de 1969 (art. 82, n. V) até se apresentar - como indicado - no art. 85, n. V da presente Carta Magna de 1988.

A improbidade administrativa se manifesta por ação ou omissão de caráter disciplinar que contraria o dever de boa administração.

Tem como sujeito ativo o servidor público ou empregado de autarquia, sociedade de economia mista e fundação pública e como sujeito passivo a pessoa jurídica administrativa cujos bens ou valores são atingidos.

Os atos ou omissões típicos da improbidade administrativa têm, como já referido, como modelos de sanções, a suspensão de direitos políticos, a perda da função pública, a indisponibilidade de bens, o ressarcimento ao erário, multa civil, bem como a proibição de contratar com o Poder Público ou de receber benefícios, incentivos ou subvenções.

A primeira das normas acima indicadas - a Lei n. 3.164/57 - institui, como medida complementar, o registro público obrigatório de valores e bens do patrimônio privado dos exercentes de cargos ou funções públicas (art. $3^{\circ}$ ).

A Lei n. 3.502/58 (Lei Bilac Pinto) que a sucedeu, definiu os casos de enriquecimento ilícito (art. $\left.2^{\circ}\right)$.

Por último, a Lei n. 8.429/92 dispôs, amplamente, sobre a determinação de atos de improbidade administrativa e as sanções aplicáveis aos agentes públicos nos casos de lesão ao patrimônio público ou pela conduta ilícita do servidor da administração direta, indireta ou fundacional.

\section{II}

Em síntese, como classifica FABIO MEDINA OSÓRIO, “a improbidade administrativa decorre da quebra do dever de probidade administrativa que descende, diretamente, do princípio da moralidade administrativa, traduzindo dois deveres fundamentais aos agentes públicos: honestidade e eficiência funcional mínima" (Improbidade administrativa $-2^{a}$ edição - fevereiro de 1998, p. 61/62).

A moralidade administrativa - à qual dedicamos estudo especial (Revista de Direito Administrativo, vol. 218, p. 1 a 10) - foi, prioritariamente traduzida, entre nós, no Decreto n. 19.398, de 11 de novembro de 1930, que instituiu o Governo Provisório da República, após a Revolução de outubro do mesmo ano.

Tem como diretrizes o dever de boa administração, a preservação dos bons costumes e a noção de equidade no confronto entre o interesse público e o dos administrados. 
O princípio da moralidade é ameaçado ou violado pela corrupção administrativa que tem raízes seculares como desvio ético, a ser combatido no plano da responsabilidade administrativa como da responsabilidade penal e civil do servidor público, ou, ainda, com a adoção de medidas preventivas, entre as quais avulta a competência do Tribunal de Contas (ver nosso estudo sobre "A moralidade administrativa e a nova Lei do Tribunal de Contas da União", in Boletim de Direito Administrativo - Editora NDJ Ltda. - n. 8.193, pp. 451/457).

Entre as formas de procedimento ilícito que podem gerar a corrupção administrativa figura a conduta funcional caracterizada pelo desvio de poder no qual, sob a aparência de legalidade, o servidor público viola essencialmente o princípio da finalidade do ato administrativo (ver nossa tese de obtenção da livre docência de Direito Administrativo na Faculdade de Direito da atual Universidade do Estado do Rio de Janeiro - 1951 - in nosso Temas de Direito Público, volume 1, p. $711 \mathrm{~s}$.).

No desvio de poder - como exprime sua denominação - o agente abandona o fim legítimo da competência para servir, entre outras hipóteses, ao enriquecimento ilícito e à corrupção administrativa.

Dediquei ao tema estudos específicos (Teoria e prática do desvio de poder Revista de Direito Administrativo, vol. $117 / 1$ e ss; $O$ desvio de poder na jurisprudência brasileira - RDA 179/180/299; o abuso de poder administrativo no Brasil Revista de Direito Administrativo, vol. 56/1 e ss.).

III

São estes, a nosso ver, os pontos fundamentais que merecem ser debatidos na avaliação da improbidade administrativa a que se destina o presente Seminário do $10^{\circ}$ Encontro Nacional de Direito Constitucional. 


\section{DICIONÁRIOS}

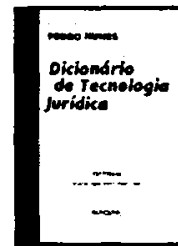

Ref. 0223

Encadernado

1.198 págs.

Form. $16 \times 23$

1999/13' edição

ISBN $85-7147 \cdot 134-7$

Dicionário de Tecnologia Juridica

\section{Pedro Nunes}

Contém definiçōes de termos, bocuçoes, expressōes e abreviaturas de Direito Romano, Civil, Comercial, Criminal, Penal Militar, Fiscal, Trabalhista, Público, Parlamentar, $\mathrm{Ca}$ nônico, Administrativo, Internacional, Judiciário, Constitucional, Politico, Diplomático e Financeiro, e, ainda, dos que são comuns na vida mercantil e econômica, na sociologia, na medicina legal, na psicologia e na psiquiatria, além de brocardos e axiomas dos Direitos romano e francês.

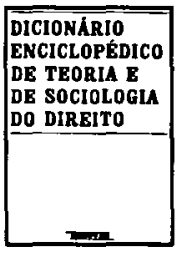

Ret. 0205

Encadernado

1.000 págs.

Form. $18,5 \times 28,5$

1999

ISBN $85 \cdot 7147 \cdot 114-2$

Dicionário Enciclopédico de

Teoria e de Sociologia do

Direito

André-Jean Arnaud (coord.)

Este dicionário é fruto de um ambicioso projeto intelectual e acadêmi$\infty$ que envolveu dezenas de juristas de todo o mundo, com expressiva participação brasileira nesta ediçăo. 0 método empregado na sua organização permite ao leitor conhecer os fundamentos do direito através de uma abordagem pluridisciplinar, voltada para uma compreensão crítica do fenômeno juridico e comprometida com a mu. danç e o aperfeiçamento do seu sistema. 